\title{
Zebra layers and palaeoenvironment of Late Miocene Stratum in the Linxia Basin, northwestern China
}

\author{
Xivqing Nian ${ }^{1,2,3}$, Xiuming $\operatorname{LiU}^{4,5,6, *}$, Hui Guo ${ }^{2,7}$, Zhi $\operatorname{LiU}^{8,9}$, Bin L $\ddot{U}^{4,5}$ \\ and FENGQING HAN ${ }^{1,3}$ \\ ${ }^{1}$ Qinghai Institute of Salt Lakes, Chinese Academy of Sciences, Xining 810008, People's Republic of China. \\ ${ }^{2}$ University of Chinese Academy of Sciences, Beijing 100049, People's Republic of China. \\ ${ }^{3}$ Qinghai Provincial Key Laboratory for Geology and Environment of Salt Lake, Xining 810008, \\ People's Republic of China. \\ ${ }^{4}$ Institute of Geography, Fujian Normal University, Fujian 350007, People's Republic of China. \\ ${ }^{5}$ Key Laboratory for Subtropical Mountain Ecology, Ministry of Science and Technology and Fujian Province, \\ College of Geographical Sciences, Fujian Normal University, Fujian 35000\%, People's Republic of China. \\ ${ }^{6}$ Department of Environment and Geography, Macquarie University, Sydney, NSW 2109, Australia. \\ ${ }^{7}$ Key Laboratory of Petroleum Resources, Gansu Province/Key Laboratory of Petroleum Resources Research, \\ Institute of Geology and Geophysics, Chinese Academy of Sciences, Lanzhou 730000, People's Republic of China. \\ ${ }^{8}$ School of Human Settlements and Civil Engineering, Xi'an Jiaotong University, Xi'an 710049, \\ People's Republic of China. \\ ${ }^{9}$ Institute of Global Environmental Change, Xi'an Jiaotong University, Xi'an 710049, People's Republic of China. \\ ${ }^{*}$ Corresponding author. e-mail: xiuminglxm@163.com
}

MS received 15 September 2017; revised 15 February 2018; accepted 10 April 2018;

published online 1 December 2018

Miocene strata in the Linxia Basin (Gansu, China) are usually interpreted as lacustrine sediments. However, the red-grey inter-beds known as 'Zebra layers' commonly tilt with respect to the terrain on the side slopes of the modern valley, which may be due to mantling palaeotopography (similar to aeolian loess). The anisotropy of magnetic susceptibility, which reflects the original arrangement of magnetic particles in sediments, was applied to investigate this phenomenon. The results showed that the tilting of the inter-beds in the side slope was due to mantle palaeotopography rather than soil creep, and that they were not deposited in a subaqueous environment. The grain sizes of sediments showed similar features as aeolian loess. We speculate that Miocene sediments were deposited by mantling the palaeotopography where aeolian materials accumulated. After deposition, flowing water submerged these strata, which caused the side slope to become gradually thinner from top to bottom and stirred the magnetic particles in these sediments. The grey colour of the Zebra layers may not be original, as it may be due to waterlogging and deoxidation after deposition; finally, when the iron oxides in these sediments were transformed or removed, their colours became grey. The formation of Zebra layers indicates that the Late Miocene palaeoenvironment of northwestern China was similar to that in which Quaternary aeolian loess was deposited.

Keywords. Late Miocene strata; Zebra layers; tilted side slope; anisotropy of magnetic susceptibility (AMS); palaeoenvironment; Linxia Basin. 


\section{Introduction}

Cenozoic red strata are widely distributed in western China, including $22 \mathrm{Ma}$ aeolian deposits in the Tianshui Basin (Guo et al. 2002), 29 Ma lacustrine sediments in the Linxia Basin (Fang et al. 2003) and $34 \mathrm{Ma}$ lacustrine sediments in the Xining Basin (Dupont-Nivet et al. 2007). Although these red strata are located close together in a single area, they appear to record contradictory information: the 6-22 Ma aeolian sediments reflect an arid environment, while the 4-29 Ma lacustrine sediments reflect a wet climate. There has been some debate about the sedimentary lithology and depositional environment of these red strata (Alonso-Zarza et al. 2009, 2010; Guo et al. 2010), indicating that the palaeogeography and palaeoclimate of this area remain controversial.

The Linxia Basin is located on the northeastern edge of the Tibetan Plateau (figure 1). This basin contains a 450-m thick Cenozoic stratum that was dated from 29 to 4 Ma by palaeomagnetism (Fang et al. 1997, 2007). This stratum provides a valuable geological record with which to understand the Cenozoic geological evolution and palaeoenvironment of northwestern China. Due to its horizontal water-lain beddings, grey colour, sediment grain sizes, magnetic parameters and chemical elements, some researchers have interpreted this Cenozoic red stratum to reflect lacustrine deposition (Fang et al. 1997, 2003, 2007; Song et al. 2005, 2007). However, the magnetic minerals of the Cenozoic sediments in the Linxia Basin are mainly magnetite, maghemite and haematite (Fang et al. 2007), which are also the main magnetic minerals of Quaternary aeolian loess and Tertiary red clay. Inspired by the detection of aeolian dust from the Pacific deepsea, Wang and Fang (2000) performed the scanning electron microscopy of 15 Ma strata from the Linxia Basin, which demonstrated that the sediments of Cenozoic strata contained aeolian sands. The particle size distributions of Cenozoic sediments from different layers indicated that both aeolian and lacustrine components were involved in this deposition ( $\mathrm{Xu}$ et al. 2008). Nd isotopic and trace element data demonstrated that aeolian dust was the main source of the fine-grained component during the accumulation process in the Linxia Basin at 29 Ma (Garzione et al. 2005). Therefore, the Cenozoic strata in the Linxia Basin may not simply reflect either lacustrine or aeolian deposition.
The overall colour of the Cenozoic stratum in the Linxia Basin is reddish, except for the approximately 100-m thick Dongxiang Formation, which is characterised by red-grey inter-beds (figure 2A-E) that developed in the Late Miocene (dated from 13.07 to $7.78 \mathrm{Ma}$ ) (Fang et al. 1997, 2007). The Dongxiang Formation has been classified as a 'Zebra layer'. Zebra layers are regarded as typical lacustrine sediments due to their horizontal waterlain beddings and grey layers (figure 2B and C). However, Zebra layers are tilted with the terrain in the side slope of the modern valley, and their thickness gradually reduces (figure $2 \mathrm{D}$ and $\mathrm{E}$ ), which is a typical feature of modern aeolian deposits. The development of drab mottles in the red beds (figure 2F) indicates that the grey layers may not be indigenous, as drab mottles are developed in red sediments due to the reduction of white Fe as water percolates through the rock (Tan et al. 2015).

Since the Cenozoic strata of the Linxia Basin remain poorly understood, especially the Zebra layers, which have similar features as aeolian deposits and were later altered, it is important to study the depositional environment and evolutionary history of the Zebra layers. Anisotropy of magnetic susceptibility (AMS) was previously applied to distinguish aeolian native loess from water-lain (secondary) Quaternary loess (Liu et al. 1990, 2010). In this study, the AMS of sediments was applied to discuss the deposition and palaeoenvironment of the Late Miocene stratum in the Linxia Basin, and its grain sizes were also analysed. The results of this study may provide evidence for better understanding the Cenozoic stratum in northwestern China.

\section{Materials and methods}

\subsection{Samples}

Four groups of orientated samples were collected from the Zebra layers of the Maomao Ditch section $\left(35^{\circ} 40^{\prime} 11^{\prime \prime} \mathrm{N}, 103^{\circ} 21^{\prime} 56.8^{\prime \prime} \mathrm{E}\right.$; figure 2D): (i) horizontal grey layers, (ii) horizontal red layers, (iii) tilted grey layers and (iv) tilted red layers. A total of 50 samples were collected from the Zebra layers. The overlying Quaternary loess of the Maomao Ditch section (figure 2D) was also collected, including 18 horizontal loess orientated samples and 17 tilted side-slope loess orientated samples. Five orientated samples were also collected from one side of a fold stratum (inclination: $42^{\circ}$; dip: $45^{\circ}$ ) of Tertiary 


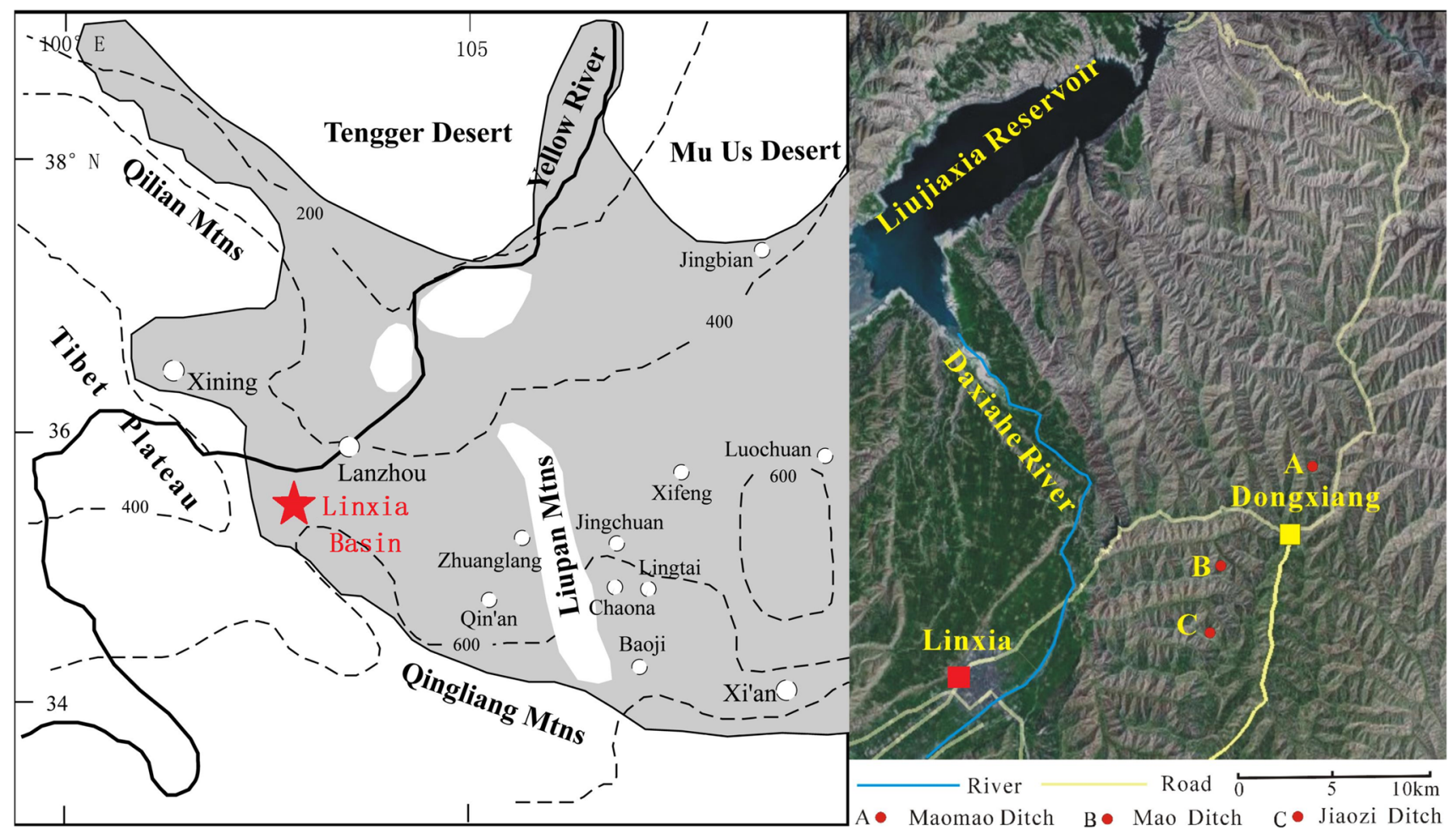

Figure 1. Location of the Linxia Basin in western China; studied sections in Dongxiang County: Maomao Ditch (A), Mao $\operatorname{Ditch}(\mathbf{B})$, and Jiaozi Ditch $(\mathbf{C})$.

red clay in the Liupan Mountains for comparison. Eighteen water-lain (secondary) loess orientated samples from the Xifeng loess section were also collected.

\subsection{Sample analysis}

The AMS of a natural rock reflects the fact that non-equiaxed magnetic particles have different demagnetisation coefficients in various directions (Bhathal 1971), which can be represented by an orthogonal magnetic ellipsoid ( $K 1 \geq K 2 \geq K 3$ ). The measured three-axis direction and magnitude of the AMS of an orientated sample $(2 \times$ $2 \times 2 \mathrm{~cm}^{3}$ ) comprise statistical results reflecting the arrangements of numerous magnetic mineral grains. The particles of natural deposits have irregular shapes, which can be approximately represented by an orthogonal triaxial ellipsoid $(a \geq b \geq$ $c)$. These two ellipsoids have the following relationship: $a / / K 1, b / / K 2, c / / K 3$. The arrangement of natural particles is challenging to measure. Therefore, a sedimentary arrangement can be assessed by studying its magnetic arrangement (Hrouda 1982; Liu et al. 1990; Tarling and Hrouda 1993). Here, the AMS was measured by a KLY-3S Kappabridge instrument (Agico, Czech Republic). Sediment grain sizes were measured by a Malvern Mastersizer 2000. Each approximately 1-g sample was treated for a period of $24 \mathrm{hr}$ with $0.5 \mathrm{~mol} / \mathrm{l} \mathrm{HCl}$ and $10 \%$ $\mathrm{H}_{2} \mathrm{O}_{2}$ to remove carbonates and organic matter, respectively. Prior to its measurement, each sample was dispersed by applying ultrasonic vibration for $30 \mathrm{~s}$. All of the above experiments were performed in the Key Laboratory of western China's Environmental System, Ministry of Education, Lanzhou University, China.

The AMS results were presented by projecting the three axes of the orthogonal magnetic ellipsoid on a 'Wushi Net'. In this study, the dots on a 'Wushi Net' represent the projection of $K 3$ of AMS, which is the minimum axis of the orthogonal magnetic ellipsoid, perpendicular to the magnetic plane determined by $K 1$ and $K 2$.

\section{Results}

\subsection{AMS analysis}

The AMS of Zebra layers showed that the dips of $K 3$ of the horizontal Zebra layer samples were nearly $90^{\circ}$, illustrating that the magnetic plane of the horizontal Zebra layers, as determined by 


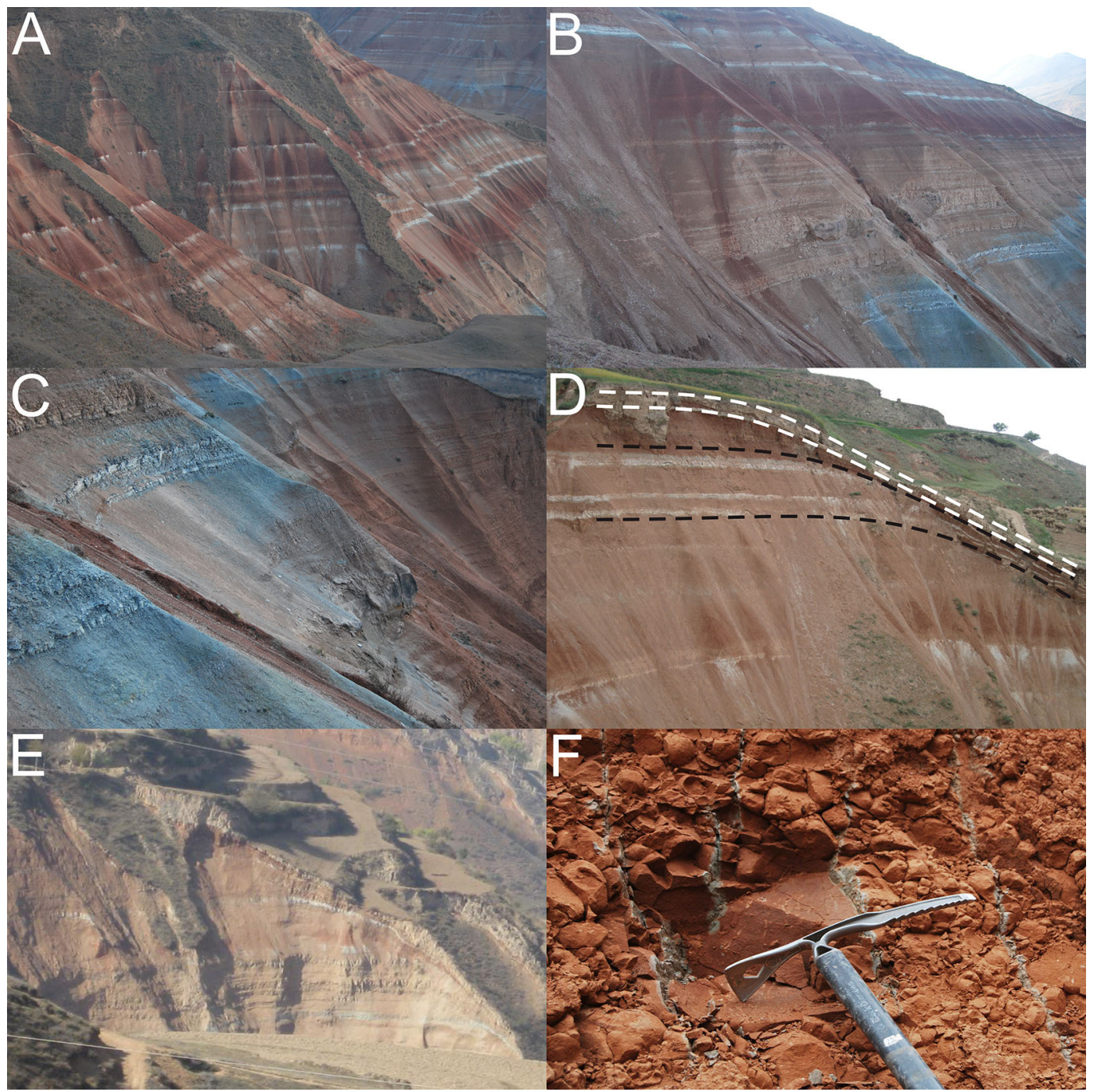

Figure 2. Sedimentary characteristics of Cenozoic strata in the Linxia Basin. Red and grey inter-bed layers (A-E) known as 'Zebra layers'; Late Miocene strata with horizontal water-lain beddings in the Jiaozi Ditch and Mao Ditch (B, C); horizontal layers gradually tilted following the topographic slopes in the Mao Ditch and Maomao Ditch (D, E); drab mottles developed in the red beds $(\mathbf{F})$. Samples of the Zebra layers (limited by two black lines) and overlying loess (limited by two white lines) were collected from the Maomao Ditch section (D).

$K 1$ and $K 2$, was generally horizontal (Hrouda 1982; Liu et al. 1990; Tarling and Hrouda 1993). The dips of $K 3$ of the tilted Zebra layer samples were unlike those of the horizontal layer samples, and they were scattered between 0 and $90^{\circ}$ (figure $3 \mathrm{~A}$ ).

The AMS of overlying Quaternary loess in the Maomao Ditch section showed that the dips of $K 3$ of both the horizontal and tilted loess layers were nearly $90^{\circ}$ (figure $3 \mathrm{~B}$ ), which suggested that the loess magnetic fabric record of dust accumulation bedding is always nearly level under subaerial conditions, regardless of how the base bed was oriented before the aeolian dust was deposited.
The water-lain samples were collected from an alluvial terrace with horizontal bedding, where aeolian loess was transported by rain or running water and redeposited in the deep valley of the Xifeng in the Loess Plateau. The AMS results showed that the $K 3$ values of water-lain loess were nearly vertical. Furthermore, the $K 3$ projections of water-lain loess, which were deposited in water, became more closed, or even better orientated, than those of native aeolian loess (figure 3C).

The AMS of five orientated samples from various positions of one side of a fold stratum (inclination: $42^{\circ}$; dip: $45^{\circ}$ ) showed that the dips of $K 3$ of the five samples were: $L 1: 39.5^{\circ}, L 2: 24.4^{\circ}$, 


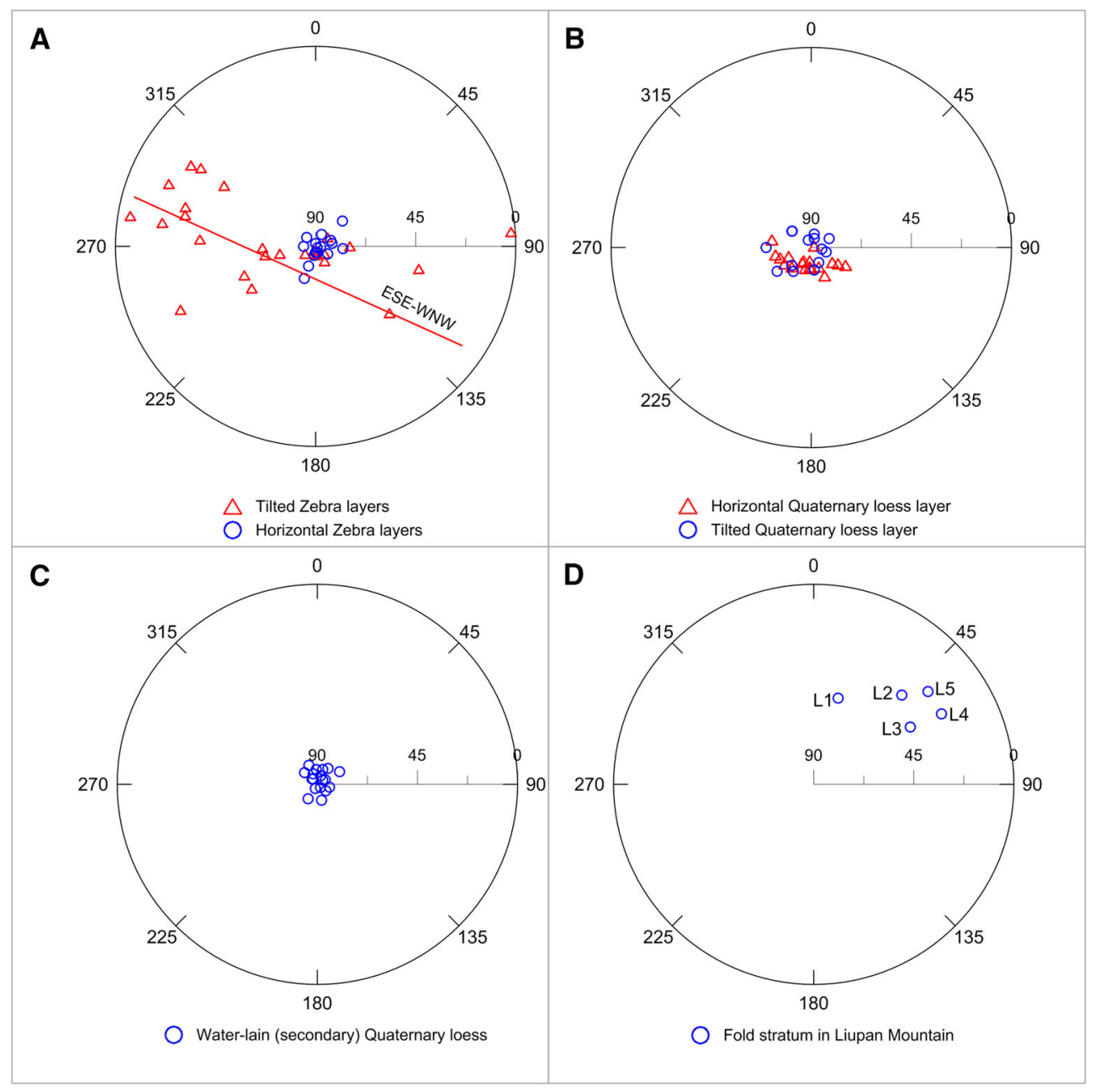

Figure 3. AMS of Zebra layers in the Linxia Basin (A), overlying Quaternary loess (B), water-lain (secondary) Quaternary loess $(\mathbf{C})$ and fold stratum in the Liupan Mountains (D).

$L 3: 33.6^{\circ}, L 4: 23.8^{\circ}$ and $L 5: 49.7^{\circ}$. The magnetic inclinations of the five samples were northeasternforward (figure 3D), which were consistent with the inclination of the fold stratum. It has been demonstrated that the Tertiary red clay represents aeolian deposits of Quaternary loess (Ding et al. 2001; Yang and Ding 2004; Lu et al. 2015); thus, the dips of $K 3$ should be nearly vertical based on the AMS results obtained from the Quaternary loess. Therefore, this Tertiary red clay stratum should originally have been nearly horizontal; due to tectonic movement, the horizontal stratum was deformed and tilted, and the dips of $K 3$ of the sediments also changed accordingly.

\subsection{Grain sizes}

Sediments deposited in different environments have different grain size characteristics (Yin 2008). The frequency curves of grain sizes showed that the sediment components of the Zebra layers (i.e., both the horizontal and tilted layers, as well as the red and grey layers) had similar properties as the overlying Quaternary loess (figure $4 \mathrm{~A}-\mathrm{F}$ ).

Based on the analysis of a large number of sediment samples from various types of sedimentary environments around the world, the "Sahu Discriminant Functions' for various kinds of sediments were calculated (Sahu 1964). One of these functions is used to distinguish airborne sediments from aquatic sediments as follows:

$$
\begin{aligned}
Y= & -3.5688 M z+3.7016 \sigma^{2}-2.0766 S K \\
& +3.1135 K_{\mathrm{G}},
\end{aligned}
$$

where $Y$ is the discriminant value, $M z$ is the average particle size, $\sigma$ is the standard deviation, $S K$ is the skewness and $K_{G}$ is the kurtosis, which is calculated using the Folk and Ward algorithm (Folk 1957). According to Sahu (1964), the 

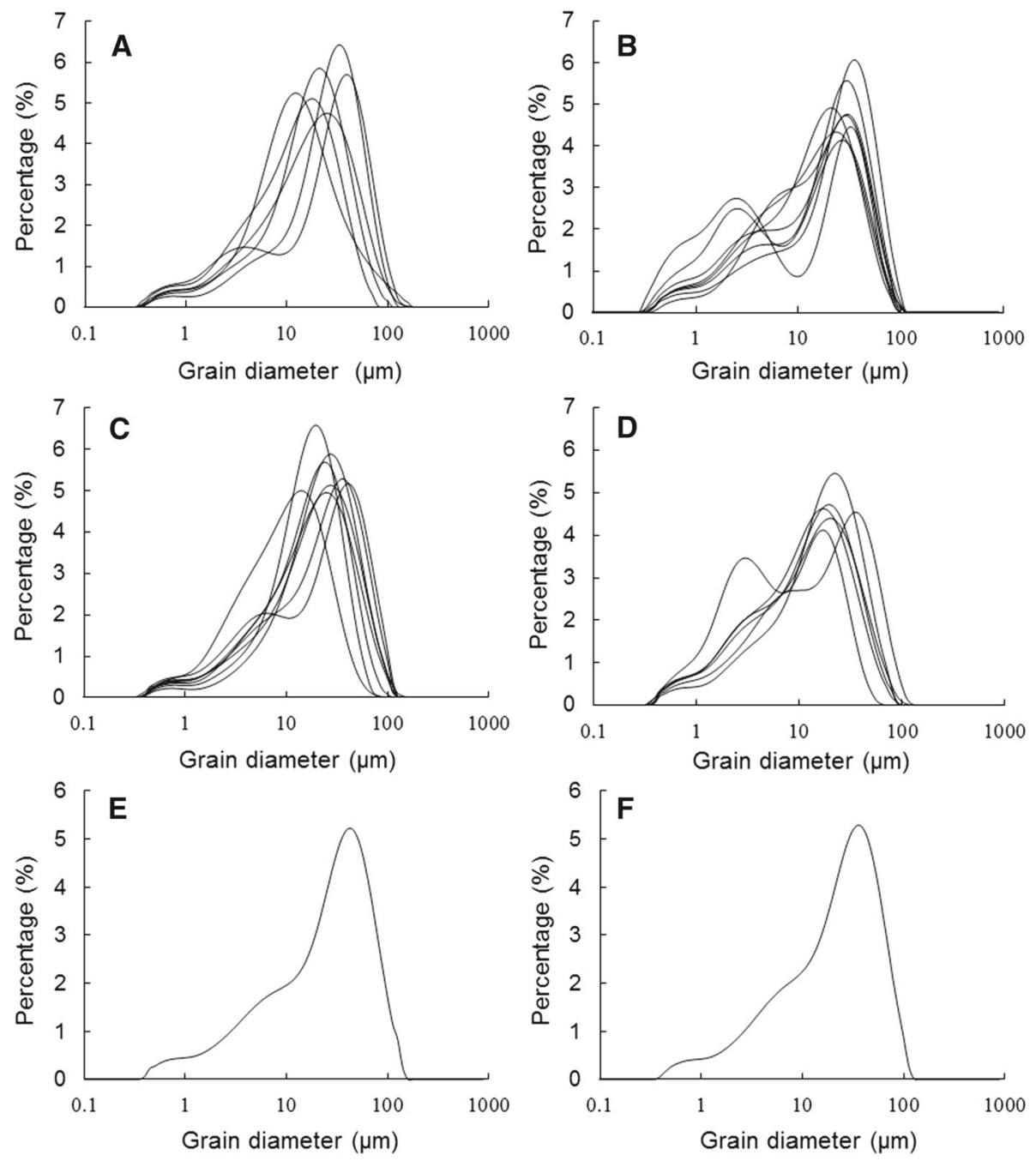

Figure 4. Frequency distribution of grain sizes of the Zebra layer sediments and overlying Quaternary loess in the Linxia Basin: horizontal grey layers (A), horizontal red layers (B), tilted grey layers $(\mathbf{C})$, tilted red layers $(\mathbf{D})$, horizontal overlying loess layer (E), and tilted overlying loess layer $(\mathbf{F})$.

discriminant value $Y$ of airborne sediments should be less than -2.7411 . In this study, the values of the environmental discriminant parameter $Y$ range from -4.55 to -14.39 , with an average value of -9.33 (figure $5 \mathrm{a}-\mathrm{d}$ ). Therefore, these data suggest that the Zebra layers are more similar to aeolian sediments than they are to lacustrine deposits.

\section{Discussion}

\subsection{Formation of Zebra layers}

The Zebra layers were previously interpreted as lacustrine deposits (Fang et al. 2003), indicating that they were deposited in a subaqueous environment. The $K 3$ projections of the Zebra layers should thus be similar to those of water-lain loess. However, the dips of $K 3$ of the tilted Zebra layer samples are scattered between 0 and $90^{\circ}$. Therefore, based on these AMS data, the Zebra layers cannot be simply explained as lacustrine deposits.

The Zebra layers are mainly horizontal, and they are only tilted in the side slope (figure $2 \mathrm{D}$ and $\mathrm{E}$ ). Soil creep or tectonic movement could have tilted the original layer. However, if tectonic movement produced the tilted stratum, its effect should not be limited to the dip of the slope, as the whole stratum should be folded into many synclines and anticlines. However, we did not observe such tectonic folds in the study area. The analysis of the fold strata of the Liupan Mountains also indicated that the Zebra layers tilted with the side slope were not due to tectonic movement, as the magnetic inclinations of the tilted Zebra layer samples were 


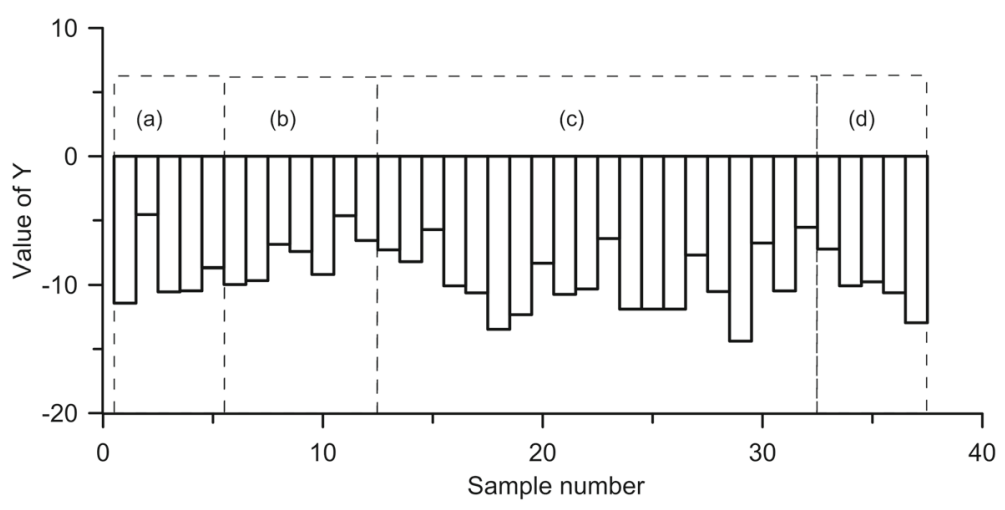

Figure 5. The discriminant value $Y$ of the Zebra layer sediments in the Linxia Basin: Horizontal grey layers (a), horizontal red layers (b), tilted grey layers $(\mathbf{c})$, and tilted red layers $(\mathbf{d})$.

not consistent with the inclination of the stratum. The tilting of the Zebra layers with the side slope was also not due to soil creep, as both soil creep and tectonic movement deformed the stratum.

The AMS results of the Quaternary loess overlying the Zebra layers showed that both the horizontal loess samples and the tilted-slope loess samples had the same features and that the dips of $K 3$ of all loess samples were nearly $90^{\circ}$. The dips of $K 3$ of the tilted Zebra layers were not similar to those of the overlying aeolian loess, which were concentrated near $90^{\circ}$, but they instead had an ESE-WNW tendency (figure 3A), which is the same as the declination of the tilted Zebra layers; thus, there may be some connection between $K 3$ and the tilted stratum.

The arrangement of the particles of natural deposits is mainly controlled by transporting fluid, such as the arrangement of cobblestones on a riverbed due to a water stream; sedimentary arrangements can be studied by analysing magnetic arrangements. The grain size data indicated that the Zebra layers have similar features as aeolian sediments, but their grey colour and the presence of water-lain beddings indicate that the Zebra layers were apparently affected by water. Therefore, we speculate that the Zebra layers most likely represent overlying loess that formed on an ancient terrain that accepted aeolian deposition and that water later flowed along this slope. That water flowed downslope and stirred the particles, which became oriented around the longest ' $a$ '-axis of the orthogonal triaxial ellipsoid; thus, the $K 3$ values were scattered between 0 and $90^{\circ}$ and exhibited a tendency along the declination of the tilted Zebra layers. Meanwhile, the water removed some of the sediment at the bottom of the side slope, causing the side slope to gradually thin from the top to the bottom.

\subsection{Palaeoenvironment of the Late Miocene Stratum in the Linxia Basin}

Many palaeosol strata developed in different geological periods (Retallack 1997, 2008, 2009; Retallack et al. 1999); some palaeosols formed 300 million years ago (Retallack 2009), and some even formed in the Precambrian (Retallack 2008). However, it remains unclear whether there are any palaeosols older than the Tertiary red clay in China.

Horizontal bedding is often attributed to lacustrine or river sediments. If sediments are flooded for a few days, this will result in horizontal bedding; if this process is repeated several times, this will produce multiple horizontal water-lain beddings. However, it can take hundreds or even thousands of years to develop a layer of palaeosol. Therefore, considering this time scale, the presence of horizontal bedding in the very thick strata in the Linxia Basin should not be interpreted as an indicator of the palaeoenvironment of the entire strata.

The Zebra layers have been interpreted to reflect lacustrine deposition due to their grey layers and red-grey inter-beds. However, the overall appearance of the Miocene layers in the Linxia Basin is dominated by a weathered, earthy red colour (figure 2A-F). Sediment colour is mainly controlled by the type and content of iron compounds (Barron and Montealegre 1986; Postma 1993; Retallack 1997). Magnetite, maghemite and haematite are all iron oxides, which are stable magnetic minerals corresponding to arid and oxidised environments. With increasing humidity, the sediment porosity 
will be filled with water instead of air, and the environment will gradually become reduced, causing these iron oxides to become unstable and finally transform into iron hydroxides (goethite and limonite) in this environment (An and Wei 1980; Han et al. 1998; Liu et al. 2001, 2007, 2008, 2010). Drab mottles developed in red strata are common phenomena in the Miocene stratum in the Linxia Basin (figure 2F); these features indicate that the grey colour may have transformed from an original red colour. After these materials were deposited, some water flowed along the cracks into the red stratum and transformed the red colour into a grey colour. Therefore, grey was not the original colour of this stratum, as red deposits are transformed into grey deposits with the loss of iron.

In addition to the presence of water-lain beddings and grey layers, there are many phenomena related to water functions in the Jiaozi Ditch, Mao Ditch and Maomao Ditch, such as the gravel layer that is developed in local regions. In the field, the number of grey layers in the Linxia Basin varies spatially: the number of grey layers in the Jiaozi Ditch was 14 (figure 2A), while that in the Maomao Ditch, which is located approximately $10 \mathrm{~km}$ to the northeast (figure 1), was only 4 (figure 2D). North of Dongxiang County, the grey stratum quickly disappeared, and this set of redgrey inter-beds was replaced by the typical Tertiary red clay stratum. Global Positioning System data showed that from the Jiaozi Ditch to the Maomao Ditch, and finally to the location where the grey layers disappeared, the altitude of the grey layers significantly increased. Therefore, although the Linxia stratum was nearly horizontal, the same layers have different altitudes in different regions. The altitude of the Jiaozi Ditch is the lowest, so it likely reserved the most water, leading to the formation of 14 red-grey Zebra layers (figure 2A); to the northeast, the altitude increases, and the stagnant water conditions became weaker, causing the number of Zebra layers to decrease and eventually disappear. The Jiaozi Ditch, Mao Ditch and Maomao Ditch are all tributaries of the Xia River (figure 1); because the formation of Zebra layers is related to water flooding, we speculate that this water may have originated from the Xia River. When the Xia River flooded, water submerged this area and temporarily formed a lake, which allowed water-lain beddings to develop, and red strata were transformed into grey layers when they were soaked. In low regions, water-lain beddings and grey layers developed, and in high regions, typical red strata developed. The majority of Miocene strata were still dominantly red in colour, and only some thin layers in local regions were transformed into grey layers, indicating that the stagnant subaqueous environment was short lived. When the temporary flood receded from the slope, the water disturbed the magnetic properties of the side-slope deposits and caused the side slope strata to thin from top to bottom. Therefore, the Late Miocene palaeoenvironment of northwestern China was similar to that in which the Quaternary aeolian loess was deposited.

\section{Conclusions}

1. AMS is an ideal tool to study deposited strata. The results of AMS showed that the Quaternary loess still has a horizontal magnetic plane in the tilted side slope.

2. AMS data showed that the Zebra layers tilted with respect to the modern slope in the Linxia Basin were not tilted by tectonic movement or soil creep, and that they likely did not form in a subaqueous environment.

3. The Zebra layers most likely formed as deposits of overlying loess atop an ancient terrain that accepted aeolian deposition; as a result of later water overflowing, the side slope gradually became thinner from the top to the bottom.

4. The grey colour of these strata may not be original; it likely indicates that the red beds were soaked and deoxidised by water after the sediments were deposited. Finally, when the iron oxides in these sediments were transformed or removed, their colour became grey.

5. The Late Miocene palaeoenvironment of northwestern China was similar to that in which Quaternary aeolian loess was deposited.

\section{Acknowledgement}

This study was financially supported by the National Natural Science Foundation of China (grant nos. 41210002; U1405231).

\section{References}

Alonso-Zarza A M, Zhao Z, Song C H, Li J J, Zhang J, Martín-Pérez A, Martín-García R, Wang X X, Zhang Y and Zhang M H 2009 Mudflat/distal fan and shallow lake sedimentation (upper Vallesian-Turolian) in the Tianshui 
Basin, Central China: Evidence against the late Miocene eolian loess; Sedim. Geol. 222 42-51.

Alonso-Zarza A M, Zhao Z, Song C H, Li J J, Zhang J, Martín-Pérez A, Martín-García R, Wang X X, Zhang Y and Zhang M H 2010 Reply to the comment on 'Mudflat/distal fan and shallow lake sedimentation (upper Vallesian-Turolian) in the Tianshui Basin, Central China: Evidence against the late Miocene eolian loess' (eds) Alonso-Zarza A M, Zhao Z, Song C H, Li J J and Zhang J, Sedim. Geol. 230 90-93.

An Z S and Wei L Y 1980 The fifth layer paleosol in the Lishi loess and their paleoclimatic significance; Acta Pedol. Sin. 17 3-10.

Barron V and Montealegre L 1986 Iron oxides and color of Triassic sediments; application of the Kubelka-Munk theory; Am. J. Sci. 286 792-802.

Bhathal R S 1971 Magnetic anisotropy in rocks; Earth-Sci. Rev. 7 227-253.

Ding Z L, Yang S L, Hou S S, Wang X, Chen Z and Liu T S 2001 Magnetostratigraphy and sedimentology of the Jingchuan red clay section and correlation of the Tertiary eolian red clay sediments of the Chinese Loess Plateau; J. Geophys. Res. Atmos. 106 6399-6408.

Dupont-Nivet G, Krijgsman W, Langereis C G, Abels H A, Dai S and Fang X M 2007 Tibetan plateau aridification linked to global cooling at the Eocene-Oligocene transition; Nature 445635.

Fang X M, Li J J, Zhu J J, Chen H L and Cao J X 1997 Division and age dating of the Cenozoic strata of the Linxia Basin in Gansu; Chin. Sci. Bull. 42 1457-1471.

Fang X M, Garzione C, Voo R V D, Li J J and Fan M J 2003 Flexural subsidence by $29 \mathrm{Ma}$ on the NE edge of Tibet from the magnetostratigraphy of Linxia Basin, China; Earth Planet. Sci. Lett. 210 545-560.

Fang X M, Xu X H, Song C H, Han W X, Meng Q Q and Masayuki T 2007 High resolution rock magnetic records of cenozoic sediments in the Linxia basin and their implications on drying of Asian inland; Quat. Sci. 27 9891000 .

Folk R L 1957 Brazos river bar, a study in the significance of grain size parameter; J. Sedim. Res. 27 3-26.

Garzione C N, Ikari M J and Basu A R 2005 Source of Oligocene to Pliocene sedimentary rocks in the Linxia basin in northeastern Tibet from Nd isotopes: Implications for tectonic forcing of climate; Geol. Soc. Am. Bull. 117 1156-1166.

Guo Z T, Ruddiman W F, Hao Q Z, Wu H B, Qiao Y S, Zhu R X, Peng S Z, Wei J J, Yuan B Y and Liu T S 2002 Onset of Asian desertification by $22 \mathrm{Myr}$ ago inferred from loess deposits in China; Nature 416159.

Guo Z T, Ge J Y, Xiao G Q, Hao Q Z, Wu H B, Zhan T, Liu L, Qin L, Zeng F M and Yuan B Y 2010 Comment on "Mudflat/distal fan and shallow lake sedimentation (upper Vallesian-Turolian) in the Tianshui Basin, Central China: Evidence against the late Miocene eolian loess (eds) Alonso-Zarza A M, Zhao Z, Song C H, Li J J, Zhang J , Martin-Perez A, Martin-Garcia R, Wang X X, Zhang Y and Zhang M H [Sedimentary Geology 222 (2009) 42-51]; Sedim. Geol. 230 86-89.

Han J, Fyfe W S and Longstaffe F J 1998 Climatic implications of the S5 paleosol complex on the Southernmost Chinese Loess Plateau; Quat. Res. 50 21-33.
Hrouda F 1982 Magnetic anisotropy of rocks and its application in geology and geophysics; Geophys. Surv. 5 37-82.

Liu X M, Xu T C and Liu D S 1990 Anisotropy of magnetic susceptibility and origin of the Chinese loess and its significance to the Quaternary research; Sci. China B $\mathbf{3 3}$ $235-245$.

Liu X M, Hesse P, Begét J and Rolph T 2001 Pedogenic destruction of ferrimagnetics in Alaskan loess deposits; Soil Res. 39 99-115.

Liu X M, Xia D S and Liu D S 2007 Discussion on two models of paleoclimatic records of magnetic susceptibility of Alaskan and Chinese loess; Quat. Sci. 27 210-220.

Liu X M, Liu T S, Paul H, Xia D S, Jiri C C and Wang G 2008 Two pedogenic models for paleoclimatic records of magnetic susceptibility from Chinese and Siberian loess; Sci. China D 51 284-293.

Liu X M, Liu T S, Xu T C, Liu C and Chen M Y 2010 The Chinese loess in Xifeng, I. The primary study on magnetostratigraphy of a loess profile in Xifeng area, Gansu province; Geophys. J. Int. 92 345-348.

Lu H, Vandenberghe J and An Z 2015 Aeolian origin and palaeoclimatic implications of the 'red clay' (north China) as evidenced by grain-size distribution; J. Quat. Sci. 16 89-97.

Postma D 1993 The reactivity of iron oxides in sediments: a kinetic approach; Geochim. Cosmochim. Acta 575027 5034.

Retallack G J 1997 Colour guide to paleosols; John Wiley and Sons, Chichester, 75p.

Retallack G J 2008 Soils of the past: An introduction to paleopedology; 2nd edn, Blackwell, London, 600p.

Retallack G J 2009 Greenhouse crises of the past 300 million years; Geol. Soc. Am. Bull. 121 1441-1455.

Retallack G J, Bestland E A and Fremd T J 1999 Eocene and Oligocene paleosols and environmental change in central Oregon; Special Paper of the Geological Society of America, $344 \mathrm{p}$.

Sahu B K 1964 Depositional mechanisms from the size analysis of clastic sediments; J. Sedim. Res. 34 2-24.

Song C H, Bai J F, Zhao Y D, Jin H B and Meng Q Q 2005 The color of lacustrine sediments recorded climatic changes from 13 to 4.5 Myr in Linxia Basin; Acta Sedim. Sin. 23 507-513.

Song C H, Lu X C, Xing Q, Meng Q Q, Xia W M, Liu $\mathrm{P}$ and Zhang P 2007 Late Cenozoic element characters and palaeoclimatic change of the Lacustrine sediments in Linxia Basin, China; Acta Sedim. Sin. 25 409-416.

Tan Y, Zhu C, Li W U, Sun W, Wang X, Jia T, Peng H and Hou R 2015 Geomophogensis on sandstone honeycombs and white spot in the Mt. Danxiashan, Guangdong province, south China; Mountain Research.

Tarling D H and Hrouda F 1993 The magnetic anisotropy of rocks; Chapman and Hall, London, 217p.

Wang J and Fang X 2000 Eolian sand deposition and its environmental significance in Linxia basin since middle Miocene; Sci. Geogr. Sin. 20 259-263.

Xu X H, Fang X M, Song C H, Fan M J and Shen J 2008 Grain-size records of Cenozoic Lacustrine sediments from Linxia Basin and the aridification of Asian Inland; J. Lake Sci. 20 65-75.

Yang S L and Ding Z L 2004 Comparison of particle size characteristics of the Tertiary 'red clay' and Pleistocene 
loess in the Chinese Loess Plateau: Implications for origin and sources of the 'red clay'; Sedimentology $\mathbf{5 1}$ $77-93$.

Corresponding editor: NAVIN JUYAL
Yin Z 2008 Multimodal grain-size distribution characteristics and formation mechanism of lake sediments; Quat. Sci. 28 345-353. 